\title{
Climate change and plant distribution and diversity refuges in Brazilian northern savannas
}

\author{
Joxleide Costa-Coutinho $^{1}$, Mário Jardim² ${ }^{2}$ Leonardo Miranda ${ }^{3}$, and Antonio Castro ${ }^{1}$ \\ ${ }^{1}$ Universidade Federal do Piauí \\ ${ }^{2}$ Museu Paraense Emílio Goeldi \\ ${ }^{3}$ Instituto Tecnológico Vale Desenvolvimento Sustentável
}

May 5, 2020

\begin{abstract}
Objective: Climate change coupled with anthropogenic events can alter the distribution of biological groups and affect the reorganization, structure, dynamics and functioning of ecosystems and their services. Despite this, predictions of impacts on Brazilian savannas are scarce. This study estimated the potential effects of climate change on peripheral plant diversity by predicting the distribution of species from Cerrado. Site: Northern Brazilian Cerrado (NBC). Methods: Ecological niche modeling was used to provide present and future projections of responses in terms of occurrence of ten woody species based on four algorithms and four future climate change scenarios for the year 2050. Potential refuge areas for conservation actions were identified, and evidence of the vulnerability of the flora was demonstrated based on the disparity between potential areas of climate stability amid current protected areas (Conservation Units - CUs). Results: The results suggested a lack of pattern between the scenarios and an idiosyncratic response of the species, indicating different impacts on plant communities and the existence of unequal stable alternative conditions, which could bring consequences to the ecological relationships and functionality of the floras. Even in the most pessimistic scenarios, most species presented an expansion of potential occurrence areas, suppressing or cohabiting with species of adjacent biomes. Typically marginal plants were the most sensitive. Key findings: Overlapping adequate habitats are concentrated in the NBC. The analysis of habitats in relation to anthropized areas and CUs demonstrate low future effectiveness in the protection of these savannas, indicating the need to create CUs that consider the potential effects of climate change.
\end{abstract}

\section{KEY WORDS}

Biodiversity forecasting modeling, Conservation, Ecological niche modeling, Northern savanna, Refuge, Woody distribution.

\section{INTRODUCTION}

Changes in climatic conditions are periodic and common in nature in different regions of the planet. They correspond to a natural cyclic process involving warming, cooling and intense geological activities of the Earth that promote various phenomena and effects, causing changes in biological systems and ecological interrelations (Oliveira, Carneiro, Vecchia, \& Baptista, 2017). However, anthropogenic actions of the last 200 years have contributed to harmful conditions, changing particle/gas concentrations in the atmosphere with the intensification of land use and occupation (Oliveira et al., 2017; IPCC, 2018), and accelerating the speed of environmental processes to the point of preventing species from adapting or finding more suitable places to live.

The increase in the average global surface temperature is one of the main concerns of the scientific community in view of its immediately noticeable effects and relation with the biosphere in general. During the last 
century, the increase recorded was of approximately $0.87^{\circ} \mathrm{C}$ above pre-industrial levels (IPCC, 2014) and if the temperature continues to rise at the current rate, the increase is estimated to reach $1.5^{\circ} \mathrm{C}$ between 2030 and 2052 (IPCC, 2018). The expected average increase in South America is $4{ }^{\circ} \mathrm{C}$, indicating a higher frequency of extreme events in Brazil, such as floods and heat waves (Marengo, 2005). Regional models indicate that by the end of the $21^{\text {st }}$ century, the most intense effects will occur in the tropical region, specifically in the Amazon and Northeast of Brazil (Nobre, Sampaio, \& Salazar, 2008).

Climate and geological transformations have triggered adaptive processes in biological communities, leading to their evolution, development, diversification, dispersion and extinction throughout the history of lineages (Costa, Veloso Filho, Aquino, \& Castro, 2012). It is particularly important to be aware of their effects on biodiversity, because of the associated changes in distribution, phenology, migration calendar, nesting success, and population sizes of species. Thus, the response of biodiversity to climate change has become a very fruitful field for research (Hughes, 2000; McCarty, 2001; Walther et al., 2002; De Marco Junior \& Siqueira, 2009; Walther, Berger, \& Sykes, 2005; Bellard, Bertelsmeier, Leadley, Thuiller, \& Courchamp, 2012), including studies with animal (Crick, 2004; Ribeiro, Sales, \& Loyola, 2018; Miranda, Imperatriz-Fonseca, \& Giannini, 2019) and plant (Siqueira \& Durigan, 2007; Simões, Zappi, Costa, Oliveira, \& Aona, 2019) assemblages. Biological interaction with climate is easily observed in geophysical patterns of vegetation distribution, reflecting different bioclimatic zones (Salazar, Nobre, \& Oyama, 2007). Within the South American climate ranges, rainforest and savanna are the predominant biomes. They are also largely deforested, what has led to worsening climate change because the removal of vegetation cover promotes a warmer and drier regional climate (Nobre et al., 2008). However, although some evidence of current extinctions is correlated with climate change, studies suggest that climate phenomena could outweigh habitat destruction as the greatest global threat to biodiversity in the coming decades (Pereira et al., 2010; Bellard et al., 2012).

Studies on Quaternary climate fluctuations and vegetation in Brazil confirm that successive expansions and retractions occurred between forests and savannas (Silva; Bates, 2002), the main habitat typologies in Brazil. Cerrado is the largest forest savanna in South America, covering $21 \%$ of the country's land area and extending marginally into Paraguay and Bolivia, behind only the Amazon Forest in terms of extension (CI, 2019). Research in tropical South America has shown Brazil as a region where significant amounts of forests are converted into non-forest areas as a result of global warming (Ledru, 2002; Sanaiotti, Martinelli, Victoria, Trumbore, \& Camargo, 2002; Salazar et al., 2007). Field observations and numerical models also indicate loss of tropical forest cover (Soares-Filho et al., 2006; Vale, Cohn-Haft, Bergen, \& Pimm, 2008; Rochedo et al., 2018; Gomes, Vieira, Salomão, \& Steege, 2019), replaced by savannas (Salazar et al., 2007); this potential reorganization of the distribution of biodiversity can affect the structure, dynamics and functioning of ecosystems and their respective contributions (Gallagher, Hughes, \& Leishman, 2013).

Research about spatiotemporal ecological representations of species has increased considerably in recent years with the advancement of geoprocessing and species distribution modeling tools by ecologists and conservation managers, and thus the need to provide efficient assessments of these predictive models (Teles, 1996; Allouche, Tsoar, \& Kadmon, 2006). Species Distribution Models (SDMs) allow spatial extrapolation of known occurrence records at different scales and generate potential distribution maps based on the effects of climate change on species distribution (Teles, 1996; Costa, Carnaval, \& Toledo, 2012; Oliveira \& Cassemiro, 2013).

Although the assessment of the effects of climate change on Brazilian biodiversity is increasing in all biomes, especially those predominantly forested and with greater species richness and endemism (Amazon and Atlantic Forest) (Aleixo, Albernaz, Grelle, Vale, \& Range, 2010), there are few attempts to predict the impacts on non-forest areas (Siqueira \& Peterson, 2003; Terribile et al., 2012). High levels of environmental devastation have made Cerrado to be included in the list of biodiversity hotspots (Myers, Mittermeier, Mittermeier, Fonseca, \& Kent, 2000; CI, 2019), and yet minimal (scientific and political-social) attention has been given to the marginal and disjointed position of the savannas of the North and Northeast, called the modern Brazilian agricultural frontier. They refer, in large part, to "MATOPIBA", a portion of the North and Northeast savannas with more than 73 million hectares (8.5\% of the Brazilian territory), recognized 
as the portion between the states of Maranhão, Tocantins, Piauí and Bahia (Heck \& Menezes, 2016) that accounts for much of Brazil's grain and fiber production (https://www.embrapa.br/tema-matopiba).

Despite its importance, there is a growing concern with maintaining biodiversity and understanding the ecological relationships among local species, intensified by projections of climate scenarios. In order to strengthen conservation strategies in this ecological transition region in central-north Brazil (from the Amazon to the Brazilian Sertão), this research applied spatial analysis procedures and modeling tools to predict the potential distribution of "marginal" species (on the edge of the Cerrado biome) in this subset of priority ecotonal biodiversity for conservation, which we are calling hereafter a sub-hotspot.

Based on the physical-environment (thematic maps) and biological (species occurrence) variables of the current times, algorithms were applied in order to model the fundamental niche and the potential area of occurrence of the species. The following questions were investigated in this study: based on the potential current occurrence range of the target species, do the impacts of future climate change on their distribution predict retraction or expansion of the forecasted occurrence of the central-north peripheral Cerrado? Do predictions of future occurrence among species of wide geographical distribution differ from those of relatively more restricted to the northern portion of the Biome? Are environmentally stable areas of future predicted scenarios located inside Conservation Units (CUs) at present? In this context, this study aimed to estimate the impact of climate change on the future extent of occurrence of peripheral cerrados of central-north Brazil.

\section{METHODS}

The geographic area investigated belongs to the central-north region of Brazil, focusing on marginal and disjunct savannas in relation to the continuous block of the Cerrado biome. The aim was to investigate the effects of climate change on different savannas showing the influence of adjacent phytogeographic domains. Projections and analyses are mainly concentrated in the North and Northeast regions (approximate limits $6^{\circ} \mathrm{N}, 19^{\circ} \mathrm{S}, 74^{\circ} \mathrm{O}$ and $34^{\circ} \mathrm{O}$ ), covering the Amazon, Cerrado, Caatinga and their ecotonal areas, involving natural climatic boundaries between rainforests, savannas and semi-arid steppes (IBGE, 2012). The studied area is one of the Cerrado's biodiversity and endemism supercenters, but lacks information on primary biological data, and therefore represents a preferred target for collections (Vieira, Costa-Coutinho, Castro, \& Martins, 2019). Furthermore, research indicates that this area is more sensitive to global climate change due to the current high rates of deforestation and landscape transformation (Salazar et al., 2007; IPCC, 2014).

\subsection{Data selection}

Species list were initially obtained from floristic data networks from Cerrado areas (http://cerrado.rbge.org.uk; Ratter et al., 2011; Castro et al., 2010; Vieira et al., 2019). In addition, twenty-one areas were sampled in the northern region of Cerrado (in the states of Piauí, Maranhão, Pará and Amapá), summary data available at https://doi.org/10.5061/dryad.9cnp5hqd4). To answer our question about possible differences in the effect of climate change on different species groups, from the 235 species recorded in our previous list, we selected five species of wide national distribution in the Biome (SpG); and five species with marginal distribution of the northern Cerrado, typical of the peripheral areas investigated and absent or rare in the central region of Brazil (SpM): Bowdichia virgilioides (754 occurrences), Byrsonima crassifolia (523), Curatella americana (956), Himatanthus articulatus (441), Parkia platycephala (259), Plathymenia reticulata (604), Qualea grandiflora (858), Q. parviflora 727), Salvertia convallariodora (561) and Vatairea macrocarpa (413) (Tab. S1 in Appendix S1). Our choice was based on the largest data set, highest constancy values in the national savanna areas and highest importance value [IV] indices in the inventoried northern savannas. Finally, in addition to inventory and field survey data, occurrence records of these species were obtained from the Global Biodiversity Information Facility open access platform (http://gbif.org) using the rgbif package (Chamberlain et al., 2019) in $R$ (R Development Core Team, 2019; S1 File in Appendix S3).

Thus, the total known distribution area of each species in South America was used for the model construction process (see below) and then projected to the focal area. We opted for the smallest spatial aggregation, restricting the presence records to a distance of $1 \mathrm{~km}$. Non-georeferenced fields, those with duplicate records 
within the minimum distance $\left(1 \mathrm{~km}^{2}\right)$, and those outside the expected distribution for the species were excluded. Although typical of Cerrado, they are plants randomly recorded in ecotonal areas under the influence of neighboring domains, and for this reason the filters were based on the checklist of the present study, in the revised floristic lists of Castro et al. (2010), Ratter et al. (2011), Vieira et al. (2019) and the Species List of the Brazilian Flora (BFG, 2018; http://floradobrasil.jbrj.gov.br). The final database included 6,106 presence records (ranging from 256 to 956; Tab. S1 in Appendix S1) for the ten native species of Brazil, which were significantly represented in Cerrado sites (Fig. S1 in Appendix S2).

WorldClim data on current climate and projections for 2050 (http://worldclim.org; Fick \& Hijmans, 2017), at a resolution of $30 \operatorname{arcseg}\left(\right.$ about $\left.1 \mathrm{~km}^{2}\right)$ within the spatial boundaries of South America $\left(12^{\circ} \mathrm{N}, 56^{\circ} \mathrm{S}, 91^{\circ} \mathrm{O}\right.$, $34^{\circ} \mathrm{O}$ ) were used for the purpose of creating ecological niche models (ENMs). This extension was used to capture the spectrum of climate variation for the entire known distribution of species. Among the 20 variables (altitude and 19 bioclimatic variables), the least collinear variables were selected using theremoveCollinearity tool (multicollinearity.cutoff $=0.75$, nb.points $=10000$ ) from the virtualspecies package (Leroy, Meynard, Bellard, \& Courchamp, 2015): altitude, annual mean temperature, max temperature of warmest month, isothermality, mean diurnal range, precipitation of coldest quarter, annual precipitation, precipitation of warmest quarter, precipitation seasonality, and precipitation of driest quarter (Fig. S2 in Appendix S2). Future climate projections were derived from two global atmosphere-ocean circulation model (AOGCM) - the Community Climate System Model (CCSM4) and the Hadley Center Global Environmental Model (HadGEM2-CC) - in two greenhouse gas concentration situations (RCPs 4.5 and 8.5) foreseen by the Fifth Assessment $\left(\mathrm{CMIP}_{5}\right)$ of the Intergovernmental Panel on Climate Change (IPCC, 2014), representing an optimistic achievable scenario and a "business-as-usual" scenario.

\subsection{Modeling runs and analyses}

To estimate the potential distribution of species, ENMs were generated in the biomod2 package (Thuiller, Georges, Engler, \& Breiner, 2019) by running four different algorithms: Generalized Linear Model (GLM), Artificial Neural Network (ANN), Random Forest (RF), and Maximum Entropy (MAXENT). Species datasets (presence + pseudo-absence records) were randomly divided into $75 \%$ for calibration (training points) and $25 \%$ for evaluation (test points) and this procedure was repeated 10 times for each set for each species. To assess the predictive power of the models, the True Skill Statistics (TSS; threshold-dependent) values (Allouche et al., 2006) and the area under the receiver operating characteristic (ROC) curve (Phillips, Anderson, \& Schapire, 2006) were measured. Sensitivity (proportion of correctly predicted presences/true positives) and specificity (proportion of correctly predicted absences/true negatives) levels were also reported. The consensus maps were generated by the committee averaging method to represent the concordances between the different runs. The lower performing models (TSS $<0.5)$ were eliminated from the consensus building process (ensemble). Thus, five consensus maps were generated per species for each scenario (one current, two RCP 4.5 and two RCP 8.5) overlapping the projected presences of species from present day to 2050 to estimate where the environmental characteristics will resemble those of current sites of occurrence, and where these species will lose, gain or maintain their distribution. Continuous species suitability values were transformed into binary data (presence/absence) using a cut-off threshold that maximized TSS (Cutoff, Tab. S1 in Appendix S1) and the projected area of occurrence was calculated by multiplying the cell area by the cell count. The modeling results were visualized through the QGIS Geographic Information System (QGIS, 2019) and analyzed using the R Statistical environment and the raster library (File S1 in Appendix S3).

We also measured the potential dynamics of change in the range extension (area gain/loss) of the species based on the differences between the projected area for each current and future climate scenario. This analysis was made for each species separately, to recognize ecological functional differences between plant populations. The size of the areas with greater climate stability (referred to as refuges in the present study) was calculated from the number of pixels considered as presence when overlapping the models of all scenarios - individually, by status (generalist $[\mathrm{SpG}]$ and marginal $[\mathrm{SpM}]$ ), and altogether. Based on these refuge maps, the future effectiveness of present CUs from a climate change perspective was measured, accounting for the size of refuge areas for SpG and SpM and both which overlap with the CUs. The data of the Brazilian CUs 
were obtained from the website of the Ministry of Environment (http://mapas.mma.gov.br).

\section{RESULTS}

The models demonstrated high levels of accuracy according to the TSS $\left(0.86^{\sim} 0.90\right)$ and ROC (all values 0.99), indicating models with predictive quality (Tab. S1 in Appendix S1). The sum of the pixels for current projections between $\mathrm{SpG}$ and SpM species showed high variation (SpG: $3.5^{\sim} 7.0$ million $\mathrm{km}^{2}$ and SpM: 2.0 7.2 million $\mathrm{km}^{2}$ ). Estimates made by AOGCM institutions, in general, maintained consistency, and the highest rates of change with more hostile effects were recorded by CCSM4 (CC) (Tab. S1 in Appendix S1, Figure 1 and S3 in Appendix S2).

The spatial pattern of suitability predicted in the ENMs, in general, indicated a potential expansion of the area considering the binary maps, and maintains a gradual increase in the predicted metrics in future scenarios, representing an increase in areas potentially suitable for the occurrence of these species in 2050 (Fig. 2, Tab. S1 in Appendix S1). Despite the expected increased range and regardless of their status (SpG or $\mathrm{SpM}$ ), it is estimated that areas with high adequacy values will be reduced, fragmented and/or displaced as the current scenario moves towards the future ones (hotter colors in Fig. 1). In different scenarios, the species S. convallariodora will be the one that will lose the most highly suitable area. The projected occurrence range continue to coincide with the Brazilian savanna, but greater interpenetrations will potentially occur in the adjunct biomes, especially in the Amazon according to our predictions (Fig. 1 and S3 in Appendix S2). On the other hand, it was predicted that the ecotonal region of central-north Brazil will gain environmental adequacy, which was something observed in the scenarios for most of the species studied.

Still regarding future projections, it is worth noting a southwestward shift, with increased extensions in the states of Mato Grosso, Rondônia and Acre, and Bolivia. The same was not seen in the northeast of Pará and Amapá, or in the other disjoint savannas, contrary to expectations. The analyses also indicated that the scenario of extension of generalist species (refuge SpG, RCP 8.5 in Fig. 3) represents the most inclusive area of suitability for the species, and that the adequate habitats of the specialist species (SpM, RCP 8.5 in Fig. 3 ) coincide with the relictual refuge of the five scenarios including all species.

In general, the results showed that most projected species are actually being favored with increased potential area and indicated a gain of range. The average gain was of $18.5 \%$ in the most optimistic scenario (2050; RCP 4.5) and $26.9 \%$ in the worst (2050; RCP 8.5, Tab. S1 in Appendix S1). Comparing the species, $H$. articulatus had the largest environmentally suitable area predicted in the current scenario (Tab. S1 in Appendix S1, Figure 1), followed by B. crassifolia ,C. americana and B. virgilioides. The average gain of these species persists throughout the scenarios until 2050, only changing their relative positions. However, three species showed no variation or a loss of spatial range: $P$. reticulata $(\mathrm{SpM})$ and $S$. convallariodora $(\mathrm{SpG})$ showed reduction in the less pessimistic ( 8 and $11 \%$, respectively) and in the most pessimistic $(3 \sim 16 \%$, respectively) scenarios. There was a similar prediction for $H$. articulatus $(\mathrm{SpM})$, with negative rates $\left(6^{\sim}\right.$ $14 \%$ ) in three of the five scenarios (Figure 2 and S4 in Appendix S2).

In future projections, the 278 protected areas of different categories that overlapped the focal areas will house only $4.6 \%\left(5,634 \mathrm{~km}^{2}\right)$ of the refuges; only $4.8 \%\left(7,822 \mathrm{~km}^{2}\right)$ and $8.1 \%\left(142,196 \mathrm{~km}^{2}\right)$ of the marginal and generalist species, respectively, will be protected inside CUs (Figure 3). Less than 10 current CUs are found specifically in relictual areas, the largest being the Ilha do Bananal/Cantão State Environmental Protection Area in Tocantins and the Chapada das Mesas National Park in southern Maranhão. When associated with vegetation loss data, a drastic and alarming reduction in the proportion of residual habitats per grid cell was observed, showing the preferred areas to concentrate on conservationist measures (Fig. S5 in Appendix S2).

\section{DISCUSSION}

With the understanding of biogeographic processes such as dispersal of organisms, creation of barriers that promote vicariance, and generation of new lineages and species (cladogenesis), it becomes clear that climate change is central to these evolutionary processes, triggering the origin and extinction of organisms within a given historical context (Haffer, 2008). Some hypotheses (such as Pleistocene refuges and Disturbance- 
vicariance) have been proposed to explain the great contemporary Neotropical and Brazilian biodiversity (Haffer, 2008; Aleixo et al., 2010). Heating and cooling cycles are thought to have triggered adaptive processes in different biological groups in the numerous paleogeographic phases. Episodes of retraction and expansion of forest and open formations combined with isolation and speciation would have affected Cerrado biodiversity (Silva \& Bates, 2002; Haffer, 2008). Regardless of the extent of space occupied by populations, the process is a change that causes impacts that are not always ideal for the environment.

It is therefore important to predict the effects not only on possible new phytogeographic arrangements, but also on habitat functionality. The results of this study demonstrate that, even in the most optimistic climate change scenarios (ie RCP 4.5), climate requirements will potentially have a strong impact on woody assemblages of savannas from the central-north portion of Brazil in the near future (2050). The ENMs estimated changes in the spatial pattern of environmental suitability for the species and flora composition at macro-regional scale and showed that $70 \%$ of the species will occupy new niches and $30 \%$ will have smaller ideal ranges.

Due to its central and ecotonal location, greater turnover can be expected in future savanna domains in response to climate change, especially in areas of steep west-east moisture gradient (Davidson et al., 2012), such as in central-north Brazil. Although the modeled species are typical of Cerrado, they are eventually recorded in ecotonal areas under the influence of neighboring domains (BFG, 2018) and, as they are heliophilous plants, they will potentially respond by expanding their habitats, possibly increasing competition within and between floras inside the Biome and in adjacent sites. Thus the generated models are inclusive for all species using all available records of occurrence within the study area, regardless of whether the distribution is exclusive to the Biome or ecotonal (typical or ecotonal species, generalist or marginal species), focusing on potentially habitable sites for these species (Siqueira \& Durigan, 2007).

Generalist species demonstrated growth in the projected range. For Beisner, Haydon, \& Cuddington (2003) it is expected that resilient species adapt to frequent environmental disturbances. The projection was not much different for species typical of the northern marginal Cerrado. However, P. reticulata, S. convallariodora and $H$. articulatus may lose climate suitability and be restricted to alternative stable states (Beisner et al., 2003), adopting new environmental equilibrium ranges as refuge zones, as is currently the case found on the edges of the Amazon domain and in the disjunct savanna fragments between the Amazon and Caatinga.

Most species showed spatial range gain in the projections, providing minimal survival conditions for heliophilous species. This corroborates the assumption of expansion of xeric environments possibly initiated in the Holocene and maintained in the present period (Simões et al., 2019). The idiosyncratic response of some species (three species showed decreased projected area) reflects the lack of a pattern in the scenarios and indicates that climate change will have a variable influence on the varied plant communities of Cerrado ("synareal floras", in personal communication by J. M. Costa-Coutinho et al. in press). Moreover, considering only the climate factor, the Climate Observatory/SEEG (http://www.observatoriodoclima.eco.br) forecasts a $72 \%$ increase over the average temperature and a decrease in precipitation, with the most negative trends in the Cerrado and the Amazon (Azevedo et al., 2018; Penereiro, Badinger, Maccheri, \& Meschiatti, 2018).

Impacts on biodiversity vary depending on the biome, and even within a biome, responses may vary at different scales (eg Siqueira \& Peterson, 2003; Siqueira \& Durigan, 2007; Terribile et al., 2012). The difficulty of native floras to adapt to climate change tends to aggravate the natural forest degradation in a few decades. Even widely distributed species can have population sizes reduced in some areas and suffer local extinction in others, in long time series with seasonal tendency to aridity (Simões et al., 2019). It can be extrapolated that the structural simplification, increased mortality, and reduced average plant density are indicators of changes caused by the "desertification" of the northeastern savannas and semi-arid steppes, the "savannization" of the Amazon, and the "erosion" of central savannas, contributing in all cases to the contemporary reduction of phylogenetic diversity and to new patterns of ecological niches (Costa, Carnaval, et al., 2012; Terribile et al., 2012).

Recent studies have shown considerable niche resilience to drought, but also interactions between defore- 
station, fire, and potential carbon storage discharge and precipitation (Davidson et al., 2012). Although the climate is a predominant driver of community changes, several current factors operate in the disturbance of habitats, preventing the recovery and/or natural growth of landscapes and interfering with the real environmental suitability. Under the conditions analyzed in this study, all species are expected to find adequate habitats in focal areas, even in the worst climate scenario. However, it is noteworthy that other environmental and anthropogenic complications were not considered, neither the inherent biological relationships of inter-population and intra-ecosystem interactions. Research has indicated the importance of soils in the distribution of plant species (Siqueira \& Durigan, 2007), but edaphic variables were not included in the projections of northern savanna, because previous analyses (see summary of data available as a file in https://doi.org/10.5061/dryad.9cnp5hqd4) pointed to the topographic and climatic attributes as the main modelers of these savannas, showing less relevance to edaphic aspects, which are subordinated to climate variations, especially the high rainfall regime of Amazonian savannas and drought and sharp thermal amplitude in the northeastern savannas. Similarly, through a modeling study in the Amazon-Cerrado transition, Dionizio et al. (2018) found that the dynamics of environmental effects along the latitude-longitudinal gradient are particularly due to climate, and then due to the frequency of fires and phosphorus limitation in the soil.

The dynamics of environmental suitability are most likely to decrease in the Cerrado-Amazon border, where deforestation is greatest and where climate and plant diversity move between ecosystems (Davidson et al., 2012). In line with these authors, lower precipitation in these ecotones will make the conditions between forest (short drought) and savanna (long drought) less limiting, promoting its expansion. However, it is not possible to measure the direction and extent of displacement in these borders because some of the adopted algorithms (MAXENT, for example) may extrapolate the projections of occurrence in their adjustments (Vale, Tarroso, \& Brito, 2014). Siqueira and Durigan (2007) showed that models generated from "pure" data, with elements from a single biome, were more effective in terms of prediction than "mixed" models, which had species with broader distribution, also occurring at edges of fragments belonging to other plant formations.

For Vale et al. (2014), the analysis of species distribution in marginal ranges (transition zones) for ecological model predictions requires greater caution in selecting the extent, resolution and boundaries of the studied area. Terribile et al. (2012) also recommend separating the different sources of uncertainties in the modeling to assess the reliability of the predictions. For this reason, three other algorithms ( $G L M, A N N, R F$ ) in addition to MAXENT, in different circulation models (AOGCMs) and scenarios, were included in the present analyses so as to increase the percentage of hits of the resulting model when compared to emission scenarios, and align the results with recent works.

The prediction of the real influence of environmental changes on the different elements that act on plant diversity is based on conjectures and are conditioned to fluctuations in direct (temperature, $\mathrm{CO}_{2}$ emission, solar radiation, precipitation, sea ice extent) and indirect (food availability, pests, soil moisture, sea level) components that impact biodiversity (IPCC, 2018). According to Costa, Carnaval, et al. (2012), the latest diversification cycles of some biological groups were correlated with recent climate changes; for other groups, though, such changes contributed little to today's richness and geographical distribution. Terribile et al. (2012) consider appropriate to examine both the past and the future in order to map the most likely areas of Cerrado in the future. In this context, assessing the consequences of variations in phenological and reproductive patterns, ecological interactions, length of annual seasons, and responses linked to adaptability, plasticity, migration or extinction in populations, for example, is to be a goal of current research (Azevedo et al., 2018; IPCC, 2018).

ENMs in Cerrado plant lineages contributes to this discussion and gives an idea of the susceptibility of this Biome to current trends in land use and chronic use of natural resources, ensuring the information of Silva and Oliveira (2018), which outlined potential areas of "topoclimate" suitability shared by species across present and future climate scenarios. The present study presented novel data showing that the largest inclusive extent of the projected refuge will potentially be concentrated in the center of the studied area 
(central-north or mid-north Cerrado), coinciding with biome "subhotspots" considered by Castro and Martins (1999) as the Cerrado's peripheral (ecotonal) boundaries of high peaks of diversity (see database available at https://doi.org/10.5061/dryad.9cnp5hqd4). As discussed by J. M. Costa-Coutinho et al. (in press ) in personal communication, lower and plastic diversity is expected from peripheral floras in fragmented, ecotonal habitats with high structural complexity acting as environmental filters that cause the homogenization of diversity (Kortz \& Magurran, 2019). But as the models show, for the species analyzed, many of these areas will provide the ideal conditions for some Cerrado communities. These results reinforce the authors' interest in this ecotonal region of high scientific interest in the meeting of supercenters of Cerrado biodiversity (Castro \& Martins, 1999; Castro et al., 2010).

Endorsing the work of Terribile et al. (2012), biodiversity concentration reservoirs are indicated as priorities for conservation actions of Brazilian savannas although the protocols, scales and focal areas are different. However, current protected areas proved to be poorly effective for relictual refuges in the modeled scenarios. The projection of the climatically stable focal area is mostly connected, but largely unprotected, overlapping degraded areas. Notably, less than $10 \%$ is housed by currently established CUs.

Disjoint refuge fragments to the northeast, south and east of the projected area do not overlap with any of the CUs. They are small remnants of natural vegetation, but without protection. Combined with climate change, deforestation and fires are the factors with the biggest impacts, stimulated by the growing importance of the northern savannas as a cultivation lands for South America, due to a growing competitive advantage. Agricultural expansion and urbanization, which are not limited to a single phytogeographic region, impose an environmental footprint that furthers the Cerrado's vulnerability. Contrary to the current environmental policy of the Brazilian government, the identification of these environmental refuges and indication for preservation represent the minimal palliative measures to stop anthropic actions, yearning for greater future effectiveness of CUs, certainly as buffer zones for these events in ecosystem functioning and conservation.

The predictive power of ENMs showed high reliability and the results provided evidence that climate change will affect the distribution performance of the ten investigated oreadic woody species and alter the potential extent of their fundamental niches. The projected occurrence range coincides with the extension of the Cerrado biome, but interpenetrations in adjunct biomes are estimated to be greater, especially in the Amazonian border. There was no pattern of displacement of species towards higher elevations and towards climatically milder areas. With the gradual atmospheric warming, plants in the central-north Cerrado will be affected even in the most optimistic scenario. In both distribution status, the pattern of climatic influence of the species was not the same, which could have consequences on the ecological relationships and functionality of the floras. The main impact for the largest number of species, consistent in most scenarios, was the expansion of potential areas of occurrence, leading to suppression or cohabitation with species of other biomes. Therefore, northern Cerrado vegetation tends to benefit from the expansion of thermal suitability, although fragmentation and/or displacement of optimal environmental suitability is expected as the scenarios advance, especially for typically marginal plants. The confluence of the most suitable areas is considered a refuge and the largest extension is foreseen in the central-north area of the studied area, mainly involving parts of Maranhão, Tocantins and Pará. Combining data from legal reserves and vegetation suppression, the protected areas as a whole have the potential to protect less than $5 \%$ of the identified stable climatic areas. The models generated here show environmental refuges for species of the central-north savannas as the most indicated areas to be focused in conservationist measures. The findings also demonstrate the insufficiency of the CUs for protecting present and future oreadic floras, thus suggesting optimizations of maintenance strategies in the Brazilian Cerrado.

\section{REFERÊNCIAS}

Aleixo, A, Albernaz, AL, Grelle, CEV, Vale, MM, \& Range, TF (2010). Mudanças climáticas e a biodiversidade dos biomas brasileiros: passado, presente e futuro. Natureza \& Conservação , 8 (2), 194-196.

Allouche, O, Tsoar, A, \& Kadmon, R (2006). Assessing the accuracy of species distribution models: prevalence, kappa and the true skill statistic (TSS). J Appl Ecol., 43, 1223-1232. 
Azevedo, TR, Costa Junior, C, Brandão Junior, A, Cremer, MS, Piatto, M, Tsai, DS, ... Kishinami, R (2018). SEEG initiative estimates of Brazilian greenhouse gas emissions from 1970 to 2015. Sci Data , 5, 180045.

Beisner, BE, Haydon, DT, \& Cuddington, K (2003). Alternative stable states in ecology. Front Ecol Environ. , 1 (7), 376-382.

Bellard, C, Bertelsmeier, C, Leadley, P, Thuiller, W, \& Courchamp, F (2012). Impacts of climate change on the future of biodiversity. Ecol Lett. , 15, 365-377.

BFG. (2018). The Brazil Flora Group. Brazilian Flora 2020: Innovation and collaboration to meet target 1 of the Global Strategy for Plant Conservation (GSPC), Rodriguésia, 69 (4), 1513-1527.

Castro, AAJF, \& Martins, FR (1999). Cerrados do Brasil e do Nordeste: caracterização, área de ocupação e considerações sobre a sua fitodiversidade. Pesquisa em Foco , 7 (9), 147-178.

Castro, AAJF, Barros, JS, Costa, JM, Santos, MPD, Pires, MFO, Mendes, MRA, .. . Sousa, SR (2010). Cerrados marginais do Nordeste e ecótonos associados: sítio 10 do PELD (Período 2001/2011). Teresina: EDUFPI/Gráfica do Povo.

Chamberlain, S, Barve, V, Mcglinn. D, Oldoni, D, Desmet, P, Geffert, L, \& Ram, K (2019). rgbif: interface to the Global Biodiversity Information Facility API. R package version 1.3.0. Retrieved from https://CRAN.Rproject.org/package $=$ rgbif.

CI. (2007). Conservation Internacional. Biodiversity Hotspots - Cerrado . Retrieved from http://www.biodiversityhotspots.org/xp/Hotspots/cerrado/Pages/default.aspx.

Costa, JLPO, Veloso Filho, FA, Aquino, CMS, \& Castro, AAJF (2012). Visão geral da biogeografia e dos sistemas universais de classificação fitogeográfica. Geografia Publicações Avulsas , 10, 36, 5-22.

Costa, TRN, Carnaval, ACOQ, \& Toledo, LF (2012). Mudanças climáticas e seus impactos sobre os anfíbios brasileiros. Revista da Biologia , 8, 33-37.

Crick, HKP (2004). The impact of climate change on birds. Ibis , 146 (1), 48-56.

Davidson, EA, Araújo, AC, Artaxo, P, Balch, JK, Brown, IF, Bustamante, MMC, ... Wofsy, SC (2012). The Amazon basin in transition. Nature , 481, 321-328.

De Marco Junior, P, \& Siqueira, MF (2009). Como determinar a distribuição potencial de espécies sob uma abordagem conservacionista? Megadiversidade , 5, 1-2.

Dionizio, EA, Costa, MHC, Castanho, AA, Pires, GF, Marimon, BS, Marimon-Junior, BH, ... Jain, AKM (2018). Influence of climate variability, fire and phosphorus limitation on the vegetation structure and dynamics in the Amazon-Cerrado border. Biogeosciences , 15, 919-936.

Fick, SE, \& Hijmans, RJ (2017). Worldclim 2: new 1-km spatial resolution climat surfaces for global land areas. International Journal of Climatology , 37 (12), 4302-4315.

Gallagher, RV, Hughes, L, \& Leishman, MR (2013). Species loss and gain in communities under future climate change: consequences for functional diversity. Ecography, 36, 531-540.

Gomes, VHF, Vieira, ICG, Salomão, RP, \& Steege, H (2019). Amazonian tree species threatened by deforestation and climate change.Nature Climate Change, 9, 547-553.

Haffer, J (2008). Hypotheses to explain the origin of species in Amazonia. Braz. J. Biol ., 68 (4), 917-947.

Heck, E, \& Menezes, L (2016). MATOPIBA: projeto de destruição do Cerrado . Porantim: em defesa da causa indígena (Vol. 37, n. 382, pp. 8-9). Brasília.

Hughes, L (2000). Biological consequences of global warming, is the signal already apparent? Trends in Ecology and Evolution, 15, 56-61. 
IBGE (2012). Instituto Brasileiro de Geografia e Estatística.Manuais técnicos em geociências: manual técnico da vegetação brasileira. Rio de Janeiro.

IPCC (2014). Intergovernmental Panel on Climate Change. Climate Change 2014 Synthesis Report Summary for Policymakers . [Cited 9 October 2019.] Retrieved from https://www.ipcc.ch/site/assets/uploads/2018/02/AR5_SYR_FINAL_SPM.pdf

IPCC (2018). Summary for Policymakers. In: Global warming of $1.5^{\circ} \mathrm{C}$. An IPCC Special Report on the impacts of global warming of $1.5^{\circ} \mathrm{C}$ above pre-industrial levels and related global greenhouse gas emission pathways, in the context of strengthening the global response to the threat of climate change, sustainable development, and efforts to eradicate poverty [V. Masson-Delmotte, P. Zhai, H. O. Pörtner, D. Roberts, J. Skea, P. R. Shukla, A. Pirani, W. Moufouma-Okia, C. Péan, R. Pidcock, S. Connors, J. B. R. Matthews, Y. Chen, X. Zhou, M. I. Gomis, E. Lonnoy, T. Maycock, M. Tignor, T. Waterfield (eds.)]. World Meteorological Organization, Geneva, Switzerland, 32 p. Retrieved from https://report.ipcc.ch/sr15/pdf/sr15_spm_final.pdf

Kortz, AR, \& Magurran, AE (2019). Increases in local richness ( $\alpha$-diversity) following invasion ares offset by biotic homogenization in a biodiversity hotspot. Biol. Lett ., 15, 20190133.

Ledru, MP (2002). Late Quaternary history and evolution of the cerrados as revealed by palynological records. In: Oliveira, PS, Marquis, RJ (Eds.), The cerrados of Brazil - Ecology and natural history of neotropical savanna . (pp. 33-50). Columbia, NY: University of New York Press.

Leroy, B, Meynard, CN, Bellard, C, \& Courchamp, F (2015). "virtualspecies, an R package to generate virtual species distributions." Ecography . Retrieved from https://doi.org/10.1111/ecog.01388

Marengo, JA (2005). Mudanças Climáticas Globais e seus efeitos sobre a biodiversidade, caracterização do clima atual e definição das alterações climáticas para o território brasileiro ao longo do século XXI . Ministério do Meio Ambiente, Brasília.

McCarty, JP (2001). Ecological consequences of recent climate change. Conservation Biology, 15, 320-331.

Miranda, LS, Imperatriz-Fonseca, VL, \& Giannini, TC (2019). Climate change impact on ecosystem functions provided by birds in southeastern Amazonia. Plos One , 11, 1-17.

Myers, N, Mittermeier, RA, Mittermeier, CG, Fonseca, GAB, \& Kent, J (2000). Biodiversity hotspots for conservation priorities. Nature , 403, 853-858.

Nobre, CA, Sampaio, G, \& Salazar, L (2008). Cenários de mudança climática para a América do Sul para o final do século 21.Parcerias Estratégicas , 13, 27.

Oliveira, HR, \& Cassemiro, FAS. (2013). Potenciais efeitos das mudanças climáticas futuras sobre a distribuição de um anuro da Caatinga Rhinella granulosa (Anura, Bufonidae).Iheringia , 103, 272-279.

Oliveira, MJ, Carneiro, CDR, Vecchia, FAS, \& Baptista, GMM (2017). Ciclos climáticos e causas naturais das mudanças do clima. Terræe Didatica , 13 (3), 149-184.

Penereiro, JC, Badinger, A, Maccheri, NA, \& Meschiatti, MC (2018). Distribuições de tendências sazonais de temperatura média e precipitação nos biomas brasileiros. Revista brasileira meteorologia, 33, 97-113.

Pereira, HM, Leadley, PW, Proença, V, Alkemade, R, Scharlemann, JPW, Fernandez-Manjarres, JF, .. . Walpole, M (2010). Scenarios foi global biodiversity in the $21^{\text {st }}$ century.Science , 10, 1496-1501.

Phillips, SJ, Anderson, RP, \& Schapire, RE (2006). Maximum entropy modeling of species geographic distributions. Ecological Modelling , 190, 231-259.

QGIS Development Team (2019). QGIS Geographic Information System . Open Source Geospatial Foundation Project.

R Development Core Team (2019). R: A language and environment for statistical computing . Viena: R Foundation for Statistical Computing, Vienna, Austria. Retrieved from https://www.R-project.org/. 
Ratter, JA, Bridgewater, S, Ribeiro, JF, Fonseca-Filho, J, Rodrigues Da Silva, M, Milliken, W, ... Pennington, RT (2011). Analysis of the floristic composition of the Brazilian Cerrado vegetation IV: revision of the comparison of the woody vegetation of 367 areas and presentation of a revised data-base of 367 areas. Royal Botanic Garden Edinburgh . Retrieved from http://cerrado.rbge.org.uk

Ribeiro, BR, Sales, LP, \& Loyola, R. (2018). Strategies for mammal conservation under climate change in the Amazon. Biodiversity Conservation, 27, 1943.

Rochedo, PRR, Soares-Filho, B, Schaeffer, R, Viola, E, Szklo, A, Lucena, AFP, .. . Rathmann, R (2018). The threat of political bargaining to climate mitigation in Brazil. Nature Climate Change , 8, 695-698.

Salazar, LF, Nobre, CA, \& Oyama, MD (2007). Climate change consequences on the biome distribution in tropical South America. Geophysical Research Letter, 34.

Sanaiotti, TM, Martinelli, LA, Victoria, RL, Trumbore, SE, \& Camargo, PB (2002). Past vegetation changes in Amazon savannas determined using carbon isotopes of soil organic matter. Biotropica , 34, 2-16.

Silva, GFN, \& Oliveira, IJ (2018). Reconfiguracao da paisagem nas savanas da Amazonia. Mercator , 17, e17028.

Silva, JMC, \& Bates, JM (2002). Biogeographic patterns and conservation in the South American Cerrado: a tropical savanna hotspot. BioScience, 52 (3), 225-234.

Simoes, SS, Zappi, D, Costa, GM, Oliveira, G, \& Aona, LYS (2019). Spatial niche modelling of five endemic cacti from the Brazilian Caatinga: Past, present and future. Austral Ecology , x, 1-13. doi.org/10.1111/aec. 12825

Siqueira, MF, \& Durigan, G (2007). Modelagem da distribuicao geografica de especies lenhosas de cerrado no Estado de Sao Paulo. Revista Brasileira de Botanica, 30 (2), 233-243.

Siqueira, MF, \& Peterson, AT (2003). Consequencias das mudancas climaticas globais na distribuicao geografica das especies de arvores do cerrado. Biota Neotropica, 3 (2), 1-14.

Soares-Filho, B, Nepstad, D, Curran, L, Cerqueira, GC, Garcia, RA, Ramos, CA, .. S Schlesinger, P (2006). Modelling conservation in the Amazon basin. Nature, 440, 520-523.

Teles, HMS (1996). Distribuicao de Biomphalaria straminea ao Sul da Regiao Neotropical, Brasil. Revista de Saude Publica, 30 (4), 341-349.

Terribile, LC, Lima-Ribeiro, MS, Araujo, MB, Bizao, N, Collevatti, RG, Dobrovolski, R, .. . Diniz-Filho, JAF (2012). Areas of Climate Stability of Species Ranges in the Brazilian Cerrado: Disentangling Uncertainties Through Time. Natureza \& Conservacao, 10 (2), 152-159.

Thuiller, W, Georges, D, Engler, R, \& Breiner, F (2019).biomod2 : Ensemble Platform for Species Distribution Modeling. R package version 3.3-7.1. Retrieved from https://CRAN.R-project.org/package=biomod2

Vale, CG, Tarroso, P, \& Brito, JC (2014). Predicting species distribution at range margins: Testing the effects of study area extent, resolution and threshold selection in the Sahara-Sahel transition zone.Diversity and Distributions, 20, 20-33.

Vale, MM, Cohn-Haft, M, Bergen, S, \& Pimm, SL (2008). Effects of future infrastructure development on threat status and occurrence of Amazonian birds. Conservation Biology, 22, 1006-1015.

Vieira, LTA, Costa-Coutinho, JM, Castro, AAJF, \& Martins, FR (2019). A biogeographic and evolutionary analysis of the flora of the North-eastern cerrado, Brazil. Plant Ecology \& Diversity, 12, 475-488.

Walther, GR, Berger, S, \& Sykes, MT (2005). An ecological 'footprint' of climate change. Proceeding of the royal society of London, 272, 1427-1432. 
Walther, GR, Post, E, Convey, P, Menzel, A, Parmesan, C, Beebee, TJC, ... Bairlein, F (2002). Ecological responses to recent climate change. Nature , 416, 389-395.

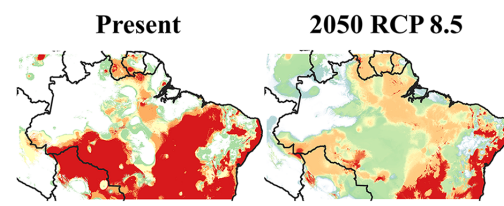

Bowdichia virgilioides
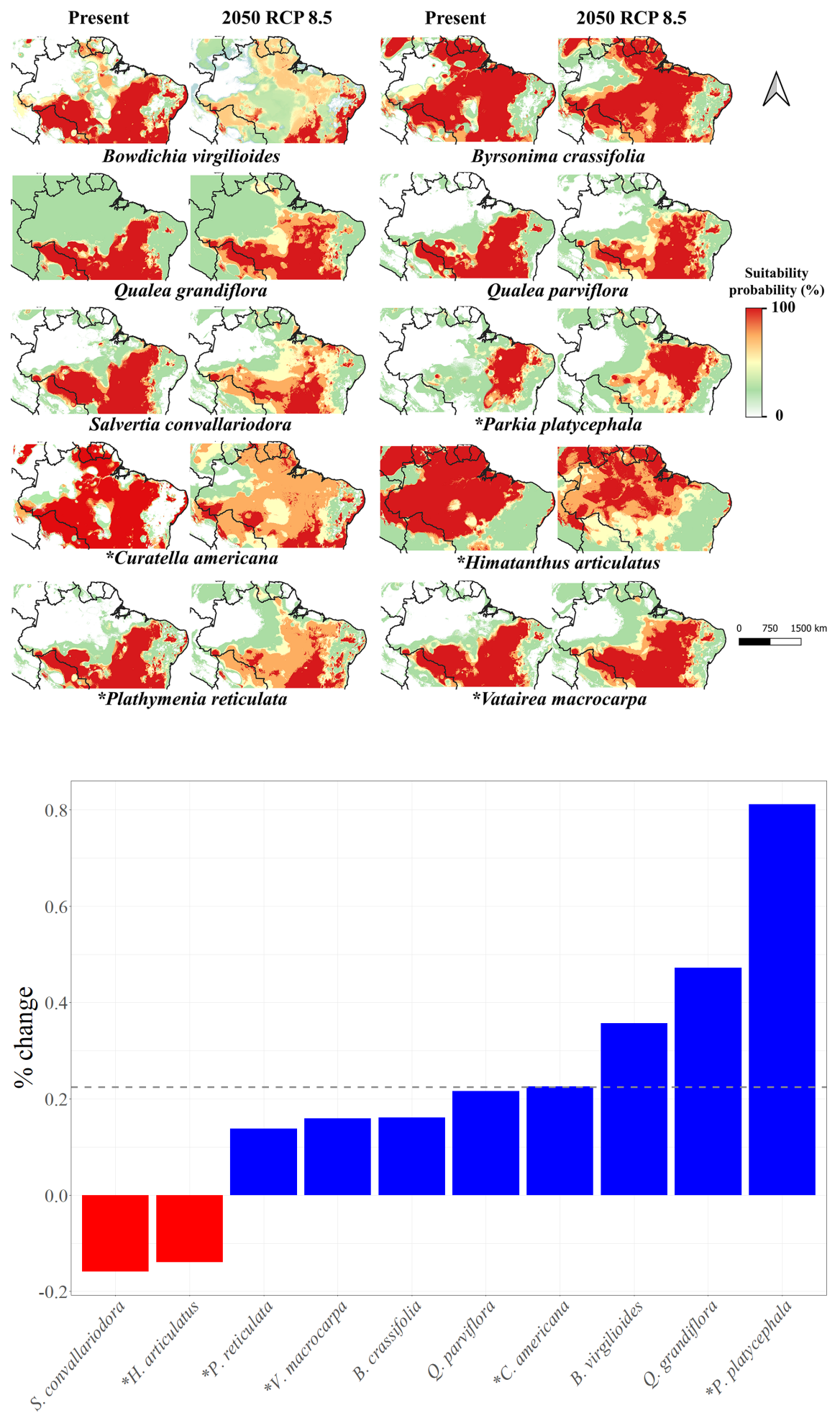

Species 


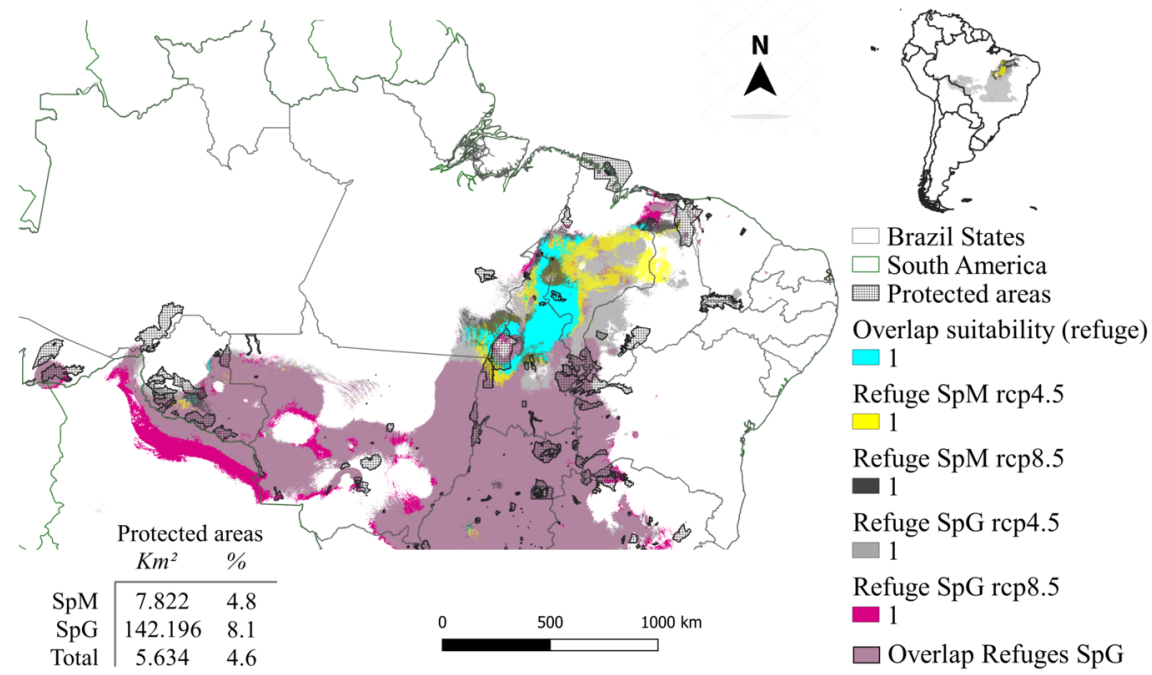



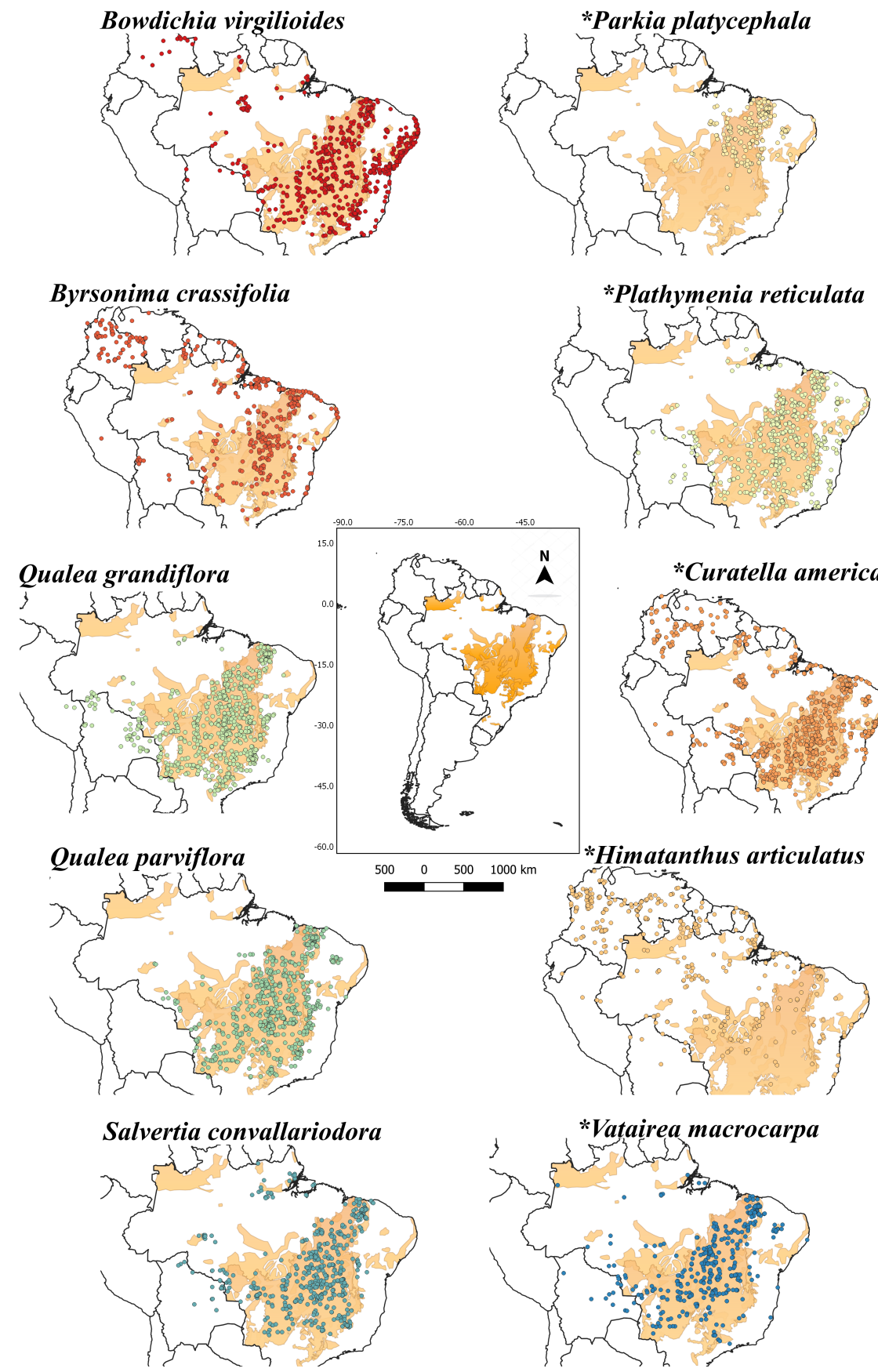


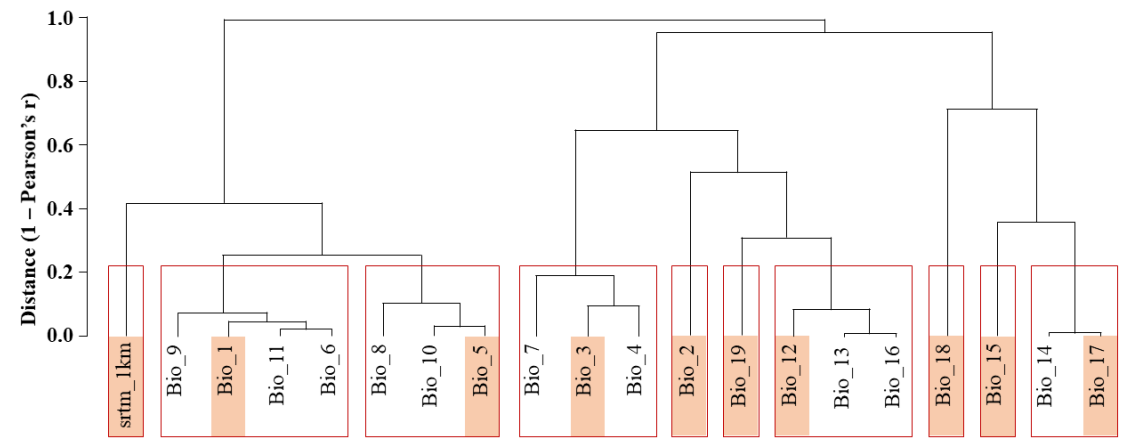

Groups of intercorrelated variables at cutoff 0.75 

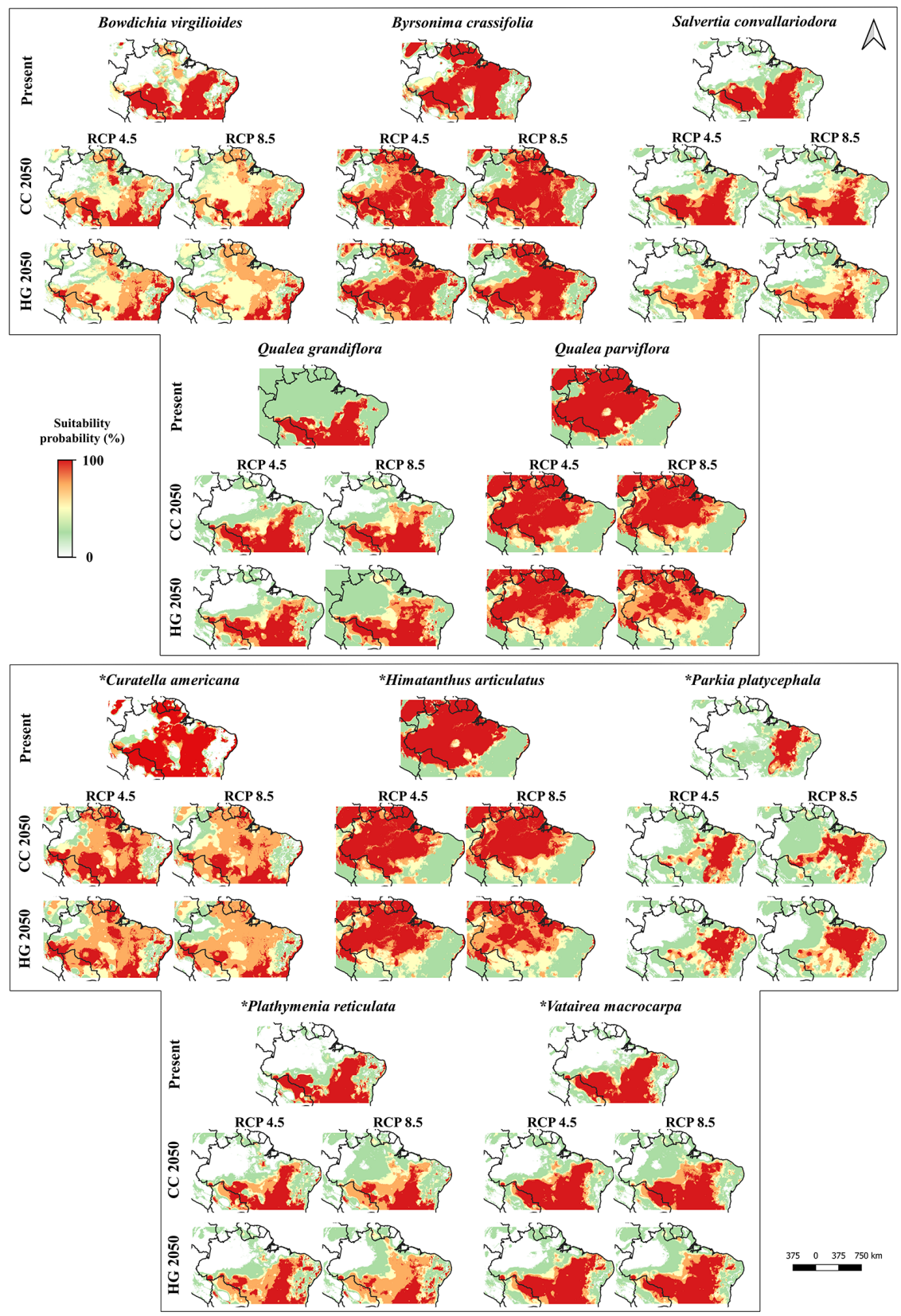

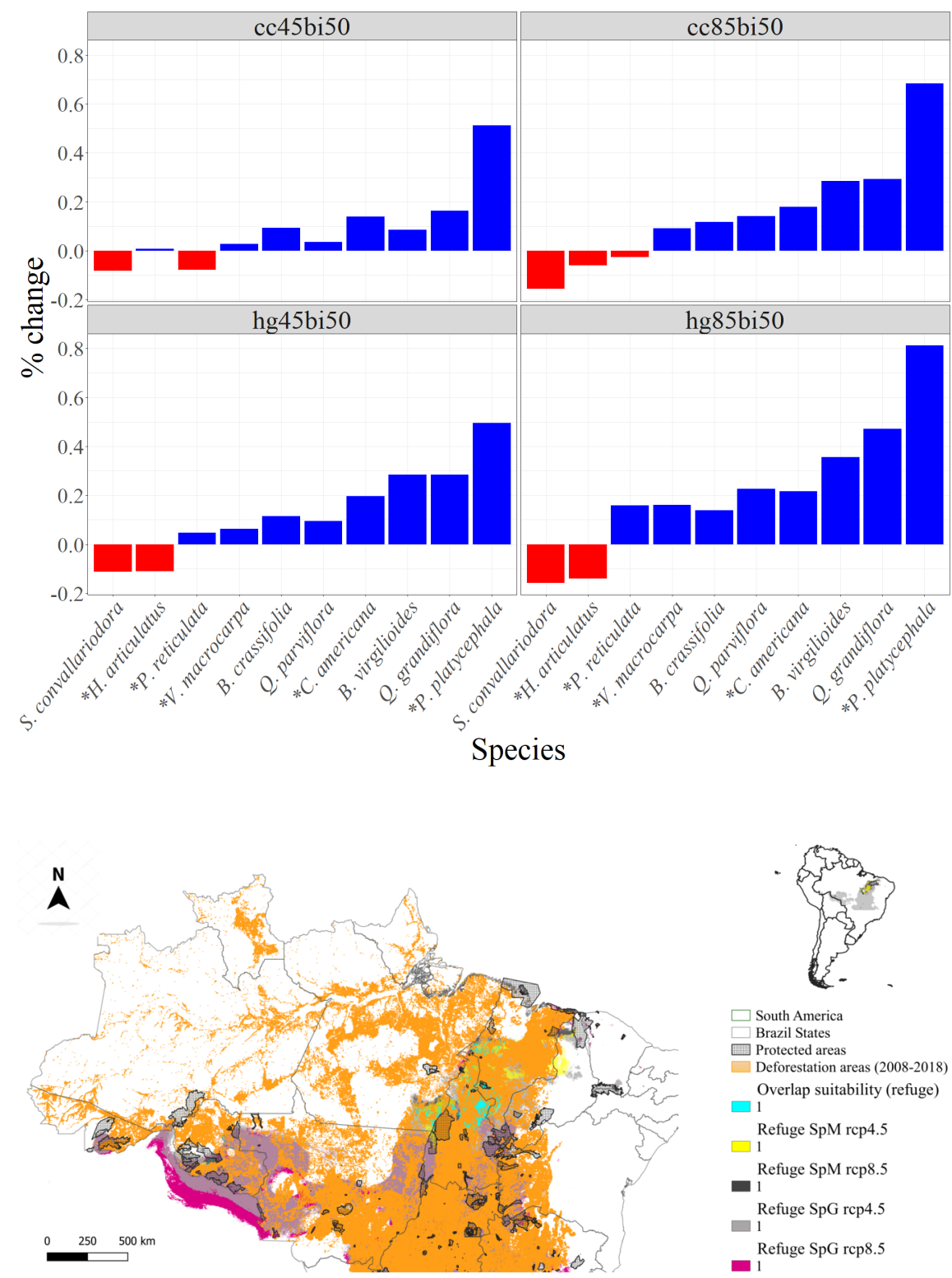